\title{
Pilotní ověrení testové baterie pohybových dovedností MOBAK jako součást kurikula sportovních her ve školní tělesné výchově
}

\section{The pilot verification of the test battery MOBAK as a part of sport oriented educational content of elementary school curriculum}

\author{
Marek Trávníček', Petr Vlček', Jaroslav Vrbas', Jiří Nykodým² \\ ${ }^{1}$ Pedagogická fakulta Masarykovy univerzity v Brně \\ ${ }^{2}$ Fakulta sportovních studií Masarykovy univerzity v Brně
}

\begin{abstract}
Abstrakt
Současné vzdělávání žáků na základní škole se odvíjí od kurikula RVP ZV. V rámci jednotlivých predmětů jsou určeny kompetence a cíle, kterých má žák dosáhnout za určitý časový úsek. Aby bylo možné zaznamenat dosažené kompetence a cile také v tělesné výchově, je nezbytné vytvářet nástroje hodnocení, které jsou prakticky použitelné pro školní tělesnou výchovu a odpovídají obsahu výuky sportovních her na 1. stupni základní školy. Cílem tohoto příspěvku je představení mezinárodní spolupráce založené na ověřování testové baterie MOBAK jako jedné z možností využití testů pohybových dovedností ve školní tělesné výchově u dětí mladšiho školního věku v České republice a představení výsledků pilotního měření na vybraných základních školách vJihomoravském kraji pomocípopisné statistiky vyhodnocení. Na základě prvotního měření jsme zjistili (n357), že výsledky podle věku jsou podobné jako v ostatních evropských zemích. Také na základě zpětné vazby zúčastněných učitelů můžeme konstatovat, že se testová baterie pohybových dovedností MOBAK 1 setkala s kladnou odezvou v praxi. Domníváme se, že je potřeba ověřit možnosti této baterie na větším počtu testovaných, a proto se snažíme o navázání hlubší spolupráce.
\end{abstract}

\begin{abstract}
Current elementary school education is based on the Framework education programmes for elementary education. Each educational area contains the characteristics of the educational area, the objectives of the educational area and its educational content. To evaluate the competencies and achieved goals also in physical education we need to create assessment tools which are applicable in the physical education classes and besides others regard also the sport games educational content of the elementary school curricula. The goal of the presented paper is to introduce an international network based on the MOBAK testing battery research. The battery presents one of the options how to test physical skills in elementary school physical education. In the paper we present some results of the pilot examination of the chosen elementary schools in the South-Moravian district of the Czech Republic. Based on the preliminary measurements (n357) we can conclude that our results are similar to the other network countries. We were also able to observe positive attitude toward using the MOBAK 1 testing battery by the participating teachers. As we find important to verify the battery on larger number of respondents we are working on the intensifying the international cooperation.
\end{abstract}

\section{Klíčová slova}

kurikulum, pohybové dovednosti, testová baterie, MOBAK 1, mladší školní věk

\section{Key words}

curriculum, physical skills, test battery, MOBAK 1, ISCED 1 
Tento př́spěvek vznikl s podporou projektu specifického výzkumu MUNI/A/0963/2015 „Výzkum kurikula vzdělávaci oblasti Člověk a zdravi" realizovaného na Pedagogické fakultě Masarykovy univerzity v Brně.

\section{Úvod}

Zdravý životní styl, jehož jednou z hlavních komponent je i pohybová aktivita, se stává stále více populární a mnoho lidí hledá ideální cesty a možnosti pohybových aktivit, jejichž součástí jsou také sportovní hry. Už od mladšího školního věku záleží na př́stupu k tělesné výchově a k rozvoji pohybových dovedností, které může dítě, později jako dospělý, využívat ve sportu, v práci, v umění, běžném životě. U dětí mladšího školního věku je důležité vytvářet podmínky pro pozitivní vnímání pohybových dovedností. Jejich zvládnutí je základním předpokladem pro uplatnění ve sportovních hrách. Pro žáky, kteří nedostatečně rozvinuli pohybové dovednosti, (sportovní hry jsou založeny na zvládnutí základních pohybových dovedností), je naprríklad obtížné manipulovat s míčem nebo jej používat při hře. Nastalá situace může vést ke ztrátě zájmu o pohyb a ubírají se k jiným činnostem, které mohou již v mladším školním věku negativně ovlivňovat jejich postoje a vztah $\mathrm{k}$ celoživotní pohybové aktivitě.

Tvůrci vzdělávací politiky se zabývají otázkou dosažených výsledků v jednotlivých předmětech. Každý předmět má poskytnout ověřitelné důkazy o tom, jakých kompetencí by měl žák dosáhnout za určitý časový úsek v procesu vzdělávání. Aby bylo možné zaznamenat účinky tělesné výchovy, je nezbytné vytvářet nástroje hodnocení, které jsou rovněž platné a praktické ve vztahu ke vzdělávacím cílům (Kurz \& Fritz, 2007).

Za tímto účelem vznikla mezinárodní testová baterie Mobak, která měří pohybové dovednosti žáků na základní škole. MOBAK, v originále „MOtorische BAsisch Kompetenzen (anglicky basic motor competencies - BAMOC), znamená základní pohybové schopnosti, které jsou vymezené jako soubor předpokladů (úspěšné) pohybové činnosti. Mobak je dále rozdělen na několik úrovní. Mobak 1 je navržen pro žáky prvního období mladšího školního věku a obsahuje elementární dovednosti jako je např́iklad hod nebo kotoul. Další úrovně Mobak 3 (je orientován na druhé období mladšího školního věku) a Mobak 5 (je orientován na druhý stupeň základní školy) mají pro testování zvolené obtížnější dovednosti.

Hlavními představiteli projektu MOBAK jsou Christian Hermann (DSBG Basel) ze Švýcarska a Claude Scheuer (University of Luxembourg) z Lucembuska.

Zatím je do mezinárodní spolupráce aktuálně zapojeno 13 evropských států (Lucembursko, Švýcarsko, Německo, Rakousko, Belgie, Řecko, Itálie, Litva, Portugalsko, Slovensko, Slovinsko, Švédsko a Česká republika) a s dalšími státy se o spolupráci jedná.

V České republice byla navázána spolupráce s katedrou tělesné výchovy a výchovy ke zdraví z Pedagogické fakulty Masarykovy univerzity v Brně.

Z pohledu historického vývoje vzniku testové baterie Mobak lze konstatovat, že je vytvářena ve spolupráci autorů ze Švýcarska, Německa a Lucemburska (Herrmann \& Seelig, 2014) na základě analýzy kurikulárních dokumentů pro základní vzdělávání v jednotlivých zemích. V ostatních zapojených zemích dochází k ověřování funkčnosti a možnostem využití testové baterie prozatím zejména na 1. stupni základní školy (MOBAK 1 a 3).

Z pohledu historického vývoje v České republice je situace s testováním pohybových dovedností na 1. stupni základní školy velmi nepřehledná. Jedním z problematických bodů je překlad z cizích jazyků. Pohybové dovednosti jsou zmiňovány u nás v poměrně velkém množství odborné literatury. Různí autoři definují pohybové dovednosti podobně, jsou zde však patrné jazykové i významové odlišnosti. Někteří autoři vycházejí z př́mého překladu např́klad anglického motor skill nebo francouzského habilité motrice, ve svých publikacích následně uvádějí motorické dovednosti. Jiní autoři použivají českého výrazu pohybové dovednosti. V některých publikacích lze nalézt jak výraz motorické dovednosti, tak pohybové dovednosti. V publikaci Motorické testy (Měkota \& Blahuš, 1983) uvádí výraz motorické dovednosti, ale v publikaci Pohybové dovednosti, činnosti, výkony (Měkota \& 
Cuberek, 2007) uvádí tento autor výraz pohybové dovednosti. Některé publikace dokonce uvádí oba výrazy v jednom textu, např́klad Vybrané kapitoly z antropomotoriky (Pavlík, 2010) mají kapitolu nazvanou Motorické dovednosti, ale hned vzápětí je napsáno, co to jsou pohybové dovednosti. Pro testy pohybových dovedností i schopností je standardně uživán výraz motorické testy vycházející z faktu, že se testuje motorika, tedy souhrn všech pohybů lidského těla, celková pohybová schopnost (hybnost) organismu. Slovo motorické je i ve spojení se získáváním nových pohybových dovedností, tzv. motorické učení. Ačkoliv se tedy pro určité oblasti měření používá i výraz motorické dovednosti, přikláníme se $\mathrm{k}$ výrazu pohybové dovednosti, jelikož je více používán u učitelů v praxi.

Publikace Motorické testy v tělesné výchově (Měkota \& Blahuš, 1983) přináší ucelený přehled historie testování tělesné zdatnosti, teorii motorických testů (jejich validitu, normovaní atd.) a výběr testů jednotlivých motorických schopností i motorických dovedností. Jsou zde zmiňovány nejen vůbec první pokusy o změření motorického výkonu, ale také postupný vývoj testů až do 80 . let 20 . století. Testům pohybových dovedností je věnována samostatná kapitola. Nejčastěji se s testováním pohybových dovedností setkáme u míčových her a plavání. Testy těchto dovedností jsou zde uvedeny jako nejlépe propracované a důležité pro tělesnou výchovu. Ve větší míře se můžeme s testy pohybových dovedností setkat $\mathrm{v}$ publikaci Vybrané kapitoly $\mathrm{z}$ teorie tělesné kultury pro specializaci tělesné výchovy 1. stupně ZŠ (Zvolská \& Gajda, 1986), kde se autoři zabývají motorickými testy především jako diagnostickými nástroji. Autoři testy rozdělují na testy pohybových schopností, pohybových dovedností a ostatní (nap̌r. držení těla). Ve vybraných motorických testech pro učitelství 1. stupně ZŠ je i výběr testů pohybových dovedností. Dále je v publikaci několik testových sestav pro žáky 1 . stupně, které však měří pohybové schopnosti. Testový profil pro 1. stupeň základní školy je určen pro měření tělesné zdatnosti 7-19leté mládeže. V publikaci je blíže specifikované měření pro 7-10letou mládež. Test je rozdělen na dvě skupiny. V první skupině se měří obecná tělesná výkonnost (pohybové schopnosti) a ve druhé skupině specifická tělesná výkonnost (pohybové dovednosti). Z pohybových dovedností je to skok daleký z rozběhu, skok vysoký, hod míčem z rozběhu a z místa, šplh na tyči s prírazem. V kapitole organizace tělesné kultury je popisován i odznak zdatnosti pro žáky na 1. stupni. Jedná se o organizační formu, která přispívá k všestrannému rozvoji tělesné zdatnosti. Žáci pro splnění testovali pohybové schopnosti (vytrvalostní běh na 12 minut) i pohybové dovednosti (hod kriketovým míčkem na dálku), další část je poplatná době vzniku odznaku zdatnosti, obsahuje prvky branné výchovy a nekoresponduje s dnešními vzdělávacími dokumenty primárního vzdělávání.

V předloženém prríspěvku je naším cílem představení mezinárodní testové baterie MOBAK 1 , která měří pohybové dovednosti žáků na základní škole. Jedná se o hodnoticí nástroj určený pro zjišt'ování úrovně pohybových dovedností žáků 1 . stupně základní školy. Jednotlivé testy pohybových dovedností vycházejí ze základů sportovních her, se kterými se žáci seznamují v rámci předmětu tělesná výchova na 1. stupni základní školy, a představení úvodního měření v ČR vyjádřené základními statistickými charakteristikami. Věŕme, že jde o komplexní testovou baterii, která na našich školách najde uplatnění.

\section{Metodika}

Hlavní metodou, kterou představujeme, je testová baterie MOBAK 1. Mezi pomocné metody můžeme zařadit deskriptivní statistiku pro základní popis zkoumaného souboru z prvotního měření v České republice v základním srovnání s vybranými evropskými státy a jako vedlejší metodu jsme využili také řízený rozhovor s učiteli, kteří se účastnili testování ve svých tř́dách.

Testování probíhalo v listopadu a prosinci 2015 a provádělo se v Hustopečích u Brna (n191) a v Jihlavě (n166). Celkem bylo otestováno 357 žáků 1.-5. ročníků vybraných základních škol. Testování probíhalo v hodinách tělesné výchovy, v tělocvičnách, které odpovídaly rozměrově i vybavením požadavkům jednotlivých testů. Sadu pomůcek, která není součástí standardní výbavy, jsme nosili s sebou. 


\section{Charakteristika testové baterie Mobak 1:}

Nejdřive je nezbytné nastudovat (seznámit se) konkrétní provedení jednotlivých elementárních pohybových dovedností v testové baterii Mobak 1 a pochopit systém jejich ohodnocení na dané škále. Důležité je stanovit si, kdy je cvik ještě považován za správně provedený a kdy už je za hranicí úspěšného pokusu. Hodnotí se pomocí nominální stupnice na základě pozorování prováděného cviku (,DSBG4public.ch”, 2016).

Při měření pohybových dovedností vychází testové baterie Mobak 1ze dvou oblastí. Jednu oblast tvoří pohyb s pomůckou a druhou oblast pohyb s vlastním tělem. V každé oblasti jsou 4 testovací úkoly, ve kterých lze získat hodnocení 0 až 8 bodů za oblast.

\section{V pohybových dovednostech s pomůckou jsou zahrnuté následující úkoly (testy):}

\section{Házení}

Předpoklad: Trefovat míčkem malý terč.

Testovaci úkol: Dítě hází z 2 m na terč 6 žonglovacími míčky.

Kritéria: Každý zásah se počítá jako bod. Pouze vrchním hodem.

Vyhodnocení: 6 pokusů, počítá se počet zásahů.

Př́prava na test: Spodní hrana je umístěna $1,30 \mathrm{~m}$ vysoko, odhodová čára je $2 \mathrm{~m}$ od terče.

Materiál: 6 žonglovacích míčků (40 g, průměr: $65 \mathrm{~mm}$ ), terč (průměr $40 \mathrm{~cm}$ ), odhodová čára.

\section{Chytání}

Předpoklad: Chytat míč.

Testovaci úkol: Dítě chytá míč po úderu na zem.

Kritéria: Míč je chycen ve vzduchu.

Vyhodnocení: 6 pokusů, počítá se počet chycení.

Příprava na test: Učitel hází míč z $2 \mathrm{~m}$ vysoko a $1,30 \mathrm{~m}$ vzdálený od žáka. Míč dosahuje výšky přibližně $1,30 \mathrm{~m}$ po dopadu na zem.

Materiál: Tenisový míč nebo gumový míč s podobnými vlastnostmi.

\section{Odrážení (basketbalový dribling)}

Předpoklad: Odrážet míč bez ztráty kontroly.

Testovaci úkol: Dítě stojí za označující čárou a odráží malý basketbalový míč směrem k druhé označené čáře bez ztráty kontroly.

Kritéria: Míč může být odražen dvěma rukama. Dítě by se mělo dívat před sebe. Míč by neměl být držen nebo ztracen z vyznačeného území. Dítě by nemělo opustit vyznačené území a nedělá žádné úkroky stranou.

Vyhodnocení: 2 pokusy, počítá se úspěšný pokus.

Připrava na test: Vytvoření území za použití lepicí pásky $(5 \mathrm{~m} \times 1 \mathrm{~m})$.

Materiál: Malý basketbalový míč (velikost 3, průměr $17 \mathrm{~cm}$ ).

\section{Dribling nohou (vedení míče)}

Předpoklad: Dribling nohou bez ztráty kontroly.

Testovaci úkol: Dítě stojí za označující čárou a dribluje nohou k druhé označené čáře bez ztráty míče. Kritéria: Míč nesmí opustit vyznačené území. Minimálně 5 kontaktů s míčem, míč může být driblován oběma nohama. Pohyb musí být plynulý bez zastavení. Pohled by měl směrovat vpřed a žádné úkroky stranou. 
Vyhodnoceni: 2 pokusy, počítá se úspěšný pokus.

Př́prava na test: Vytvoření území za použití lepicí pásky $(5 \mathrm{~m} \times 1 \mathrm{~m})$.

Materiál: Míč (soft, průměr $21 \mathrm{~cm}$ ), vyznačovací páska.

\section{Pohybové dovednosti vlastního těla zahrnují úkoly (testy):}

\section{Rovnováha}

Předpoklad: Balancování přes houpačku.

Testovaci úkol: Dítě balancuje přes houpačku (lavička na můstku) bez opuštění lavičky.

Kritéria: Plynulý přechod po lavičce bez stoupnutí mimo nebo spadnutí. Normální chůze (ne poloviční kroky).

Vyhodnocení: 2 pokusy, počítá se úspěšný pokus.

Př́prava na test: Lavička je umístěna opačnou stranou na můstku a podložena gymnastickými žíněnkami po celé délce.

Materiál: Lavička (4m délka, 38 cm výška, $10 \mathrm{~cm}$ šiřka balanční plochy), odrazový můstek (18-21 cm výška), gymnastické žíněnky na podložení po celé délce lavičky.

\section{Kotoul}

Předpoklad: Kotoul vpřed.

Testovaci úkol: Dítě předvádí kotoul, který je plynulý, a je schopno po něm vstát.

Kritéria: Při provedení mohou být použity ruce. Nepočítá se kotoul provedený na stranu. Základem je plynulost celého pohybu.

Vyhodnocení: 2 pokusy, počítá se úspěšný pokus.

Př́prava na test: 2 gymnastické žíněnky jsou umístěny za sebou.

Materiál: 2 gymnastické žíněnky.

\section{Skákání}

Předpoklad: Skákání vpřed opakovaně.

Testovaci úkol: Dítě skáče mezi a vedle čtverců plynule. Skáče jednou nohou mezi čtverce a roztaženýma nohama vedle čtverce.

Kritéria: Nesmí se dotknout čtverce. Skok musí být plynulý (pauza maximálně 1s).

Dítě může měnit odrazovou nohu mezi čtverci.

Vyhodnocení: 2 pokusy, počítá se úspěšný pokus.

Př́prava na test: 4 kobercové čtverce za sebou a mezi nimi $40 \mathrm{~cm}$ mezera.

Materiál: 4 kobercové čtverce $(40 \mathrm{~cm} \times 40 \mathrm{~cm})$.

\section{Cval stranou}

Předpoklad: Plynulý cval stranou.

Testovaci úkol: Dítě začíná od prvního kuželu, pohybuje se plynule cvalem stranou ke druhému kuželu a zpět bez změny strany. Dvakrát po sobě tam a zpět je považováno za jeden pokus.

Kritéria: Plynulý cval stranou (podmínka jedna noha musí být ve vzduchu). Boky zůstávají paralelně. Změna směru musí být provedena až za úrovní kuželu.

Vyhodnocení: 2 pokusy, počítá se úspěšný pokus.

Př́prava na test: 2 kužely, vzdálenost mezi nimi jsou $3 \mathrm{~m}$.

Materiál: 2 kužely. 


\section{VÝSLEDKY}

V deskriptivní statistice se budeme snažit přiblížit výsledky vybraných ukazatelů, které nám pomohou $\mathrm{k}$ lepší orientaci $\mathrm{v}$ dalších výsledkových částech. Nejdřive představíme celkové výsledky rozdělené pouze na pohybové dovednosti s pomůckou (object movement) a pohybové dovednosti pouze s vlastním tělem (self movement).

\section{Popisná charakteristika testové baterie MOBAK 1}

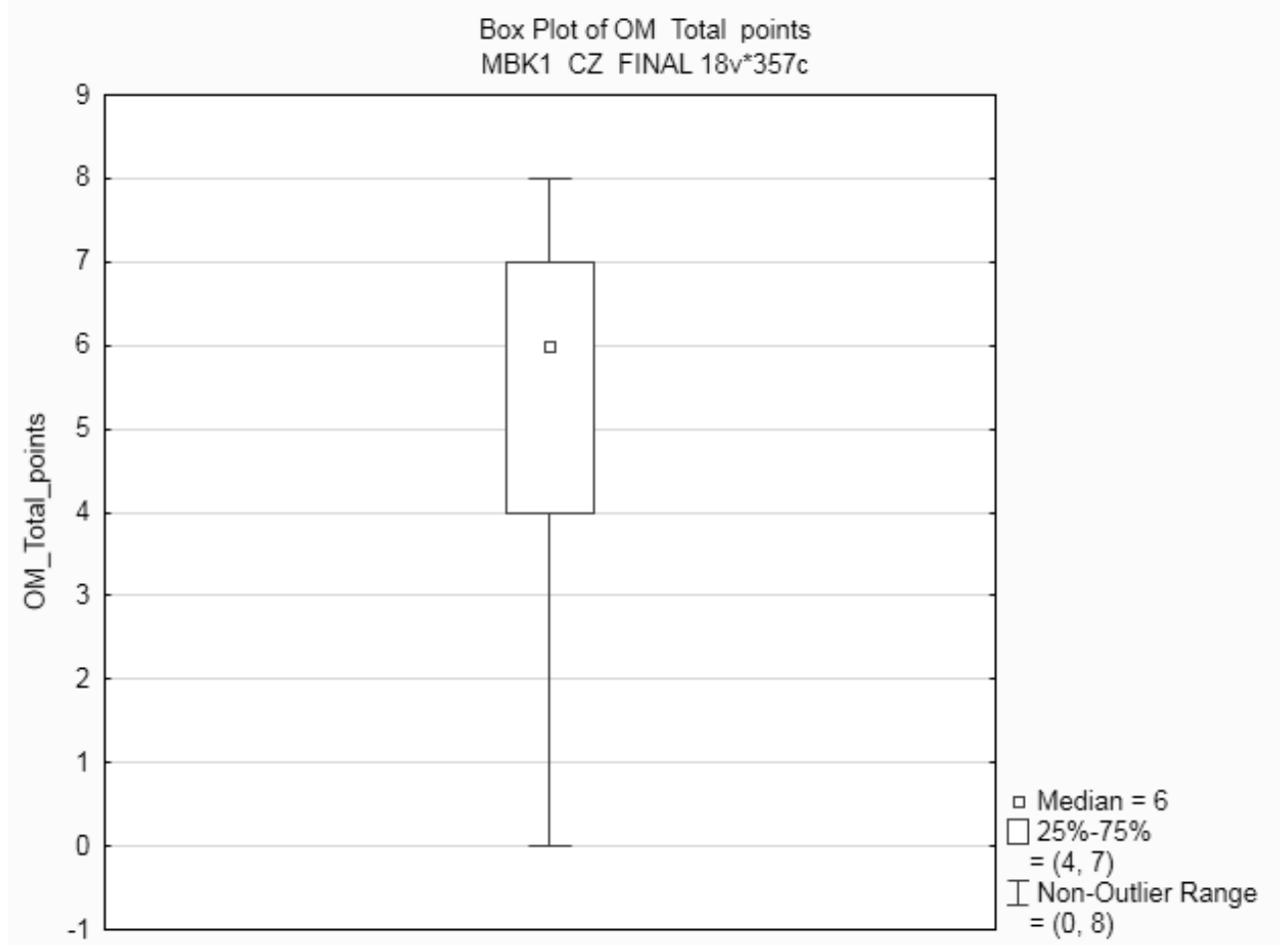

Obr. 1. Celkové hodnocení pohybových dovednostís pomůckou.

Úvodní graf v podobě krabicového diagramu nám ukazuje rozložení výsledků celkem (n357) v oblasti pohybových dovedností s pomůckou (object movement), kdy nejnižší možný počet bodů mohl být 0 a nevyšší 8 bodů za splnění 4 testů. V celkovém hodnocení jsou zastoupeny všechny bodové možnosti. Také je vidět, že $75 \%$ testovaných se nachází v bodovém hodnocení 4 až 8 bodů s mediánem 6 , což ukazuje, že v celkovém hodnocení ze všech ročníků se sice objevují hodnoty od 0 bodů, ale většina se nachází v nadprůměrných hodnotách. 


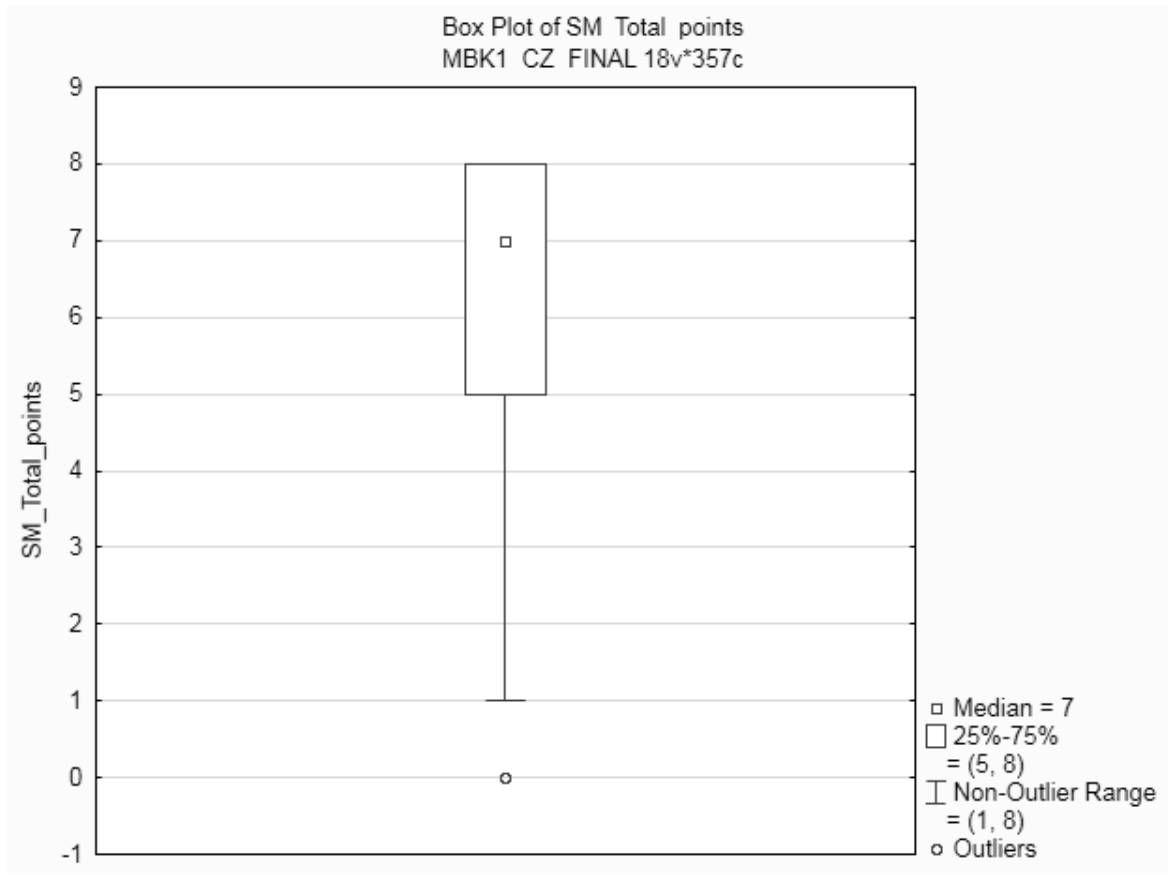

Obr. 2. Celkové hodnocení pohybových dovednostís vlastním tělem.

Krabicový diagram výše (Obr. 2.) nám ukazuje rozložení výsledků celkem (n357) v oblasti pohybových dovedností s vlastním tělem (self movement), kdy nejnižší možný počet bodů mohl být 0 a nejvyšší 8 bodů za splnění 4 testů. V celkovém hodnocení jsou zastoupeny všechny bodové možnosti, ale u bodového hodnocení 0 nacházíme osamocenou hodnotu. $75 \%$ testovaných spadá do rozmezí 5 až 8 bodů a medián je 7 . Z grafu je zřejmé, že v celkovém hodnocení (n357) dopadli testovaní lépe $\mathrm{v}$ oblasti pohybových dovedností s vlastním tělem. 


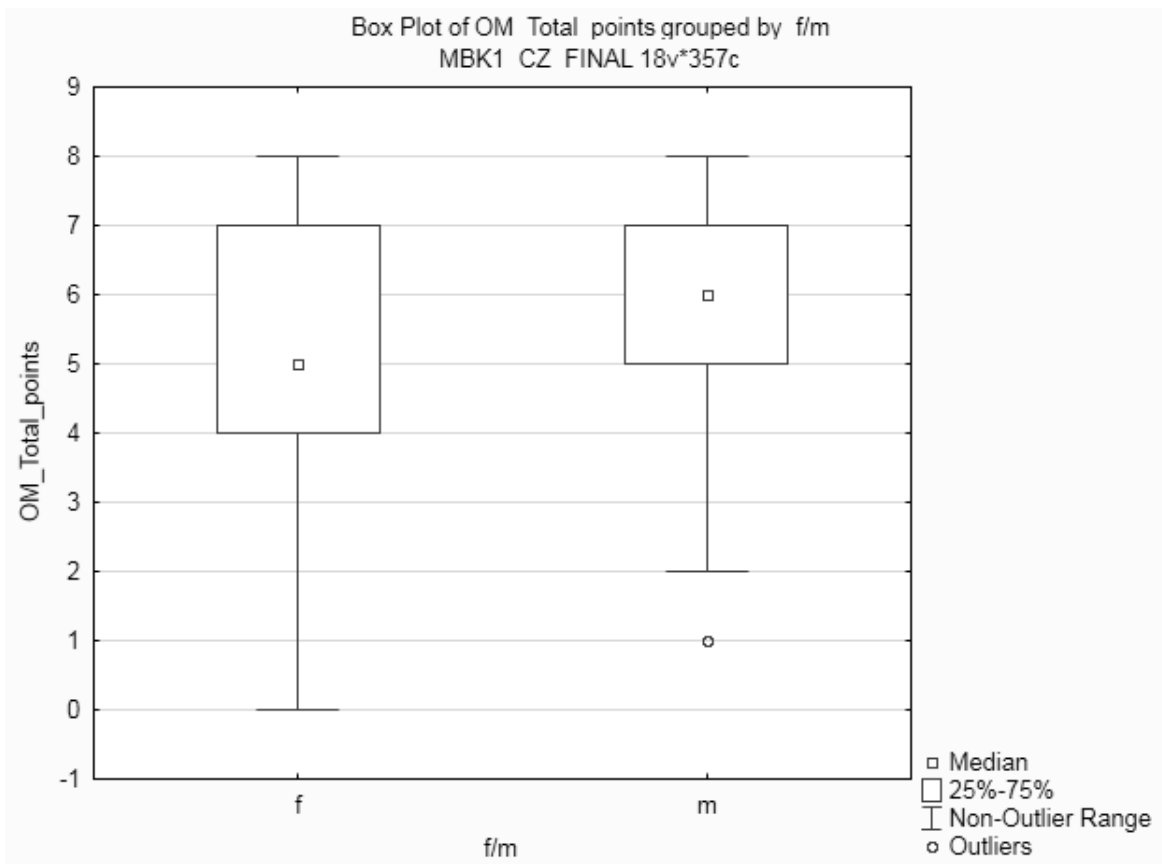

Obr. 3. Celkové hodnocení pohybových dovednostís pomůckou dívky a hoši.

Z výše uvedeného grafu je vidět, že u hochů převažuje lepší bodové hodnocení v testech pohybových dovedností s pomůckami. Medián u hochů je 6 a u dívek 5. Liší se také rozpětím, kde chlapci mají nejnižší bodovou hodnotu 1 (osamocenou), ale dívky začínají již na bodové hodnotě 0 .

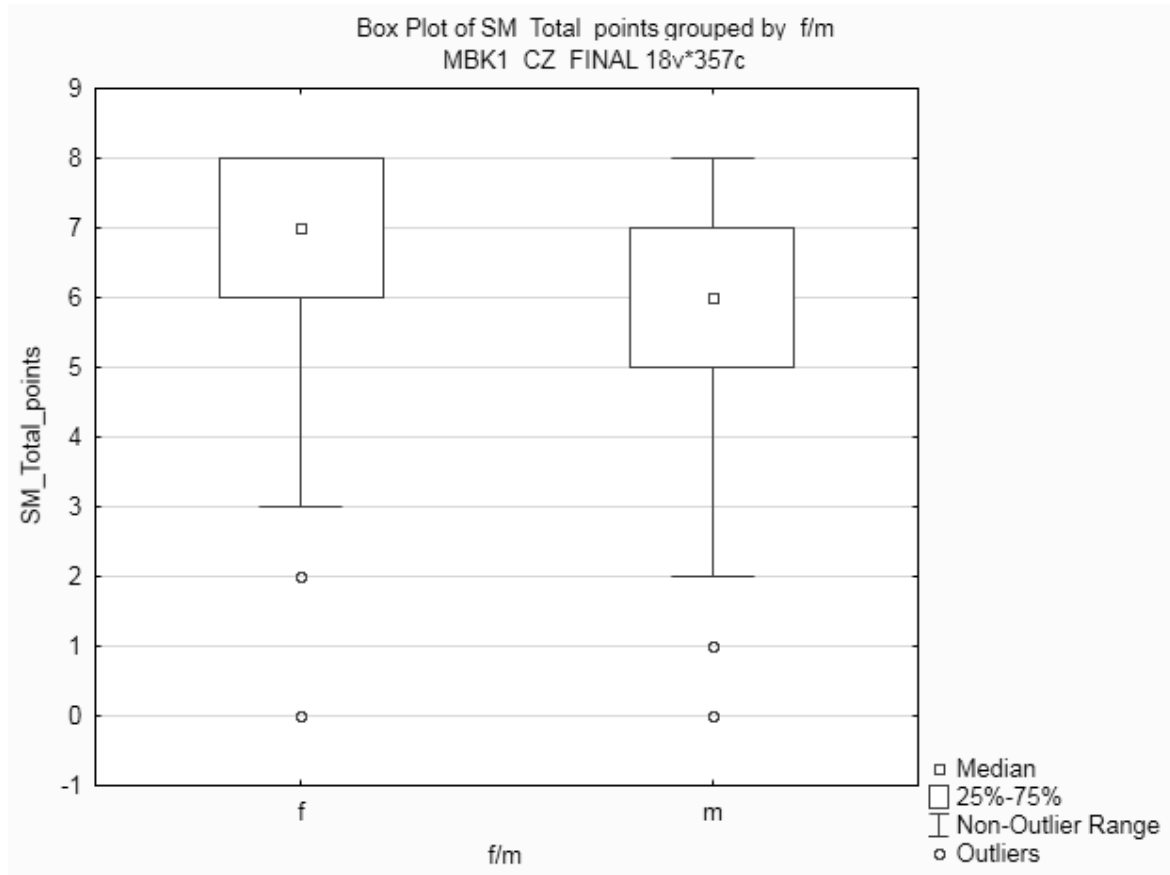

Obr. 4. Celkové hodnocení pohybových dovednostís vlastním tělem dívky a hoši. 
Z výše uvedeného grafu je vidět, že u dívek převažuje lepší bodové hodnocení v testech pohybových dovedností s vlastním tělem. Medián u hochů je 6 a u dívek 7. Liší se také rozpětím, kde chlapci mají 2 až 8 a dívky 3 až 8 . V grafu se také vyskytují osamocené bodové hodnoty 0 (u dívek i chlapců) a 1 bod u chlapců a 2 body u dívek. U dívek se $75 \%$ vešlo do bodového hodnocení 6 až 8 bodů a u hochů je $75 \%$ v rozmezí 5 až 8 bodů.

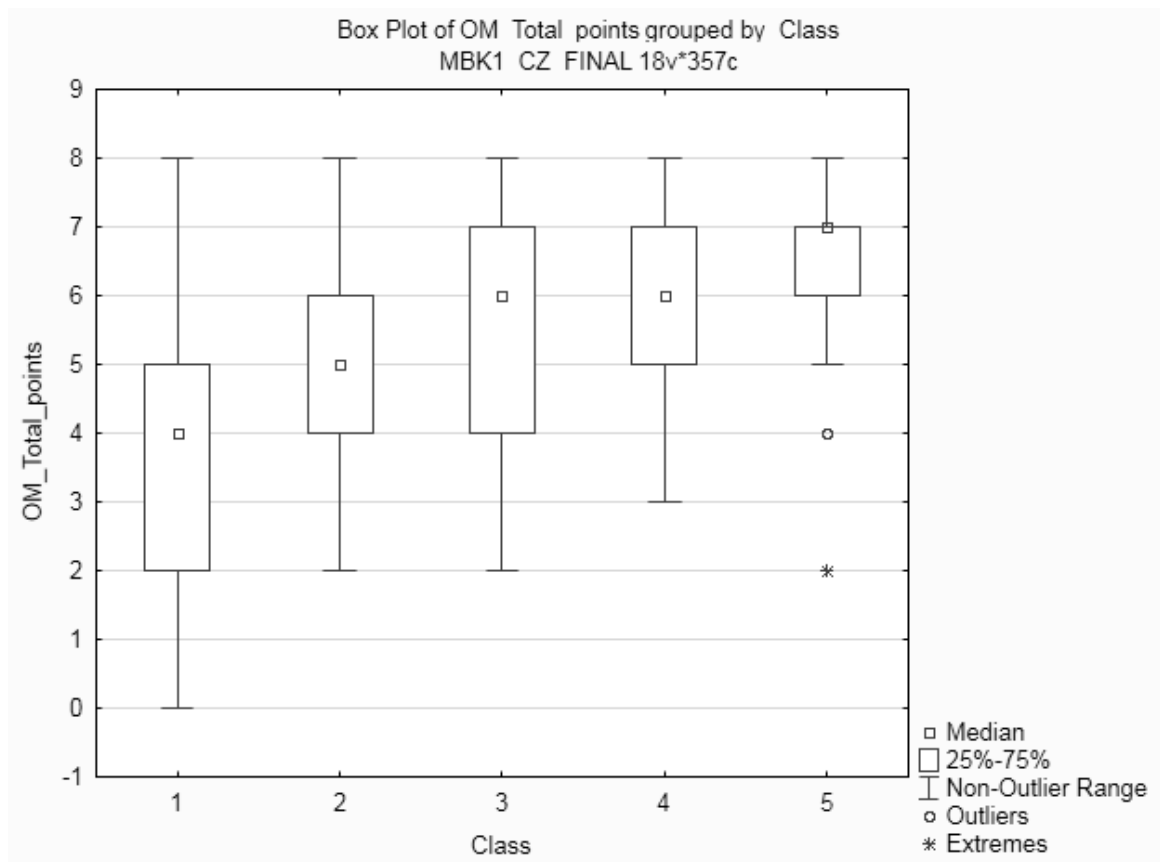

Obr. 5. Hodnocení pohybových dovedností s pomůckou podle ročníků.

Z krabicového grafu (Obr. 5.) je patrné, že nejlepších výsledků dosahují děti v 5. ročníku, i když se zde vyskytuje osamocená hodnota 4 a extrémní hodnota 2. Ideálnímu rozložení hodnot se nejvíce přibližuje 1. ročník. Srovnáním mediánů můžeme pozorovat postupné zlepšování bodového hodnocení od prvního do pátého ročníku. 


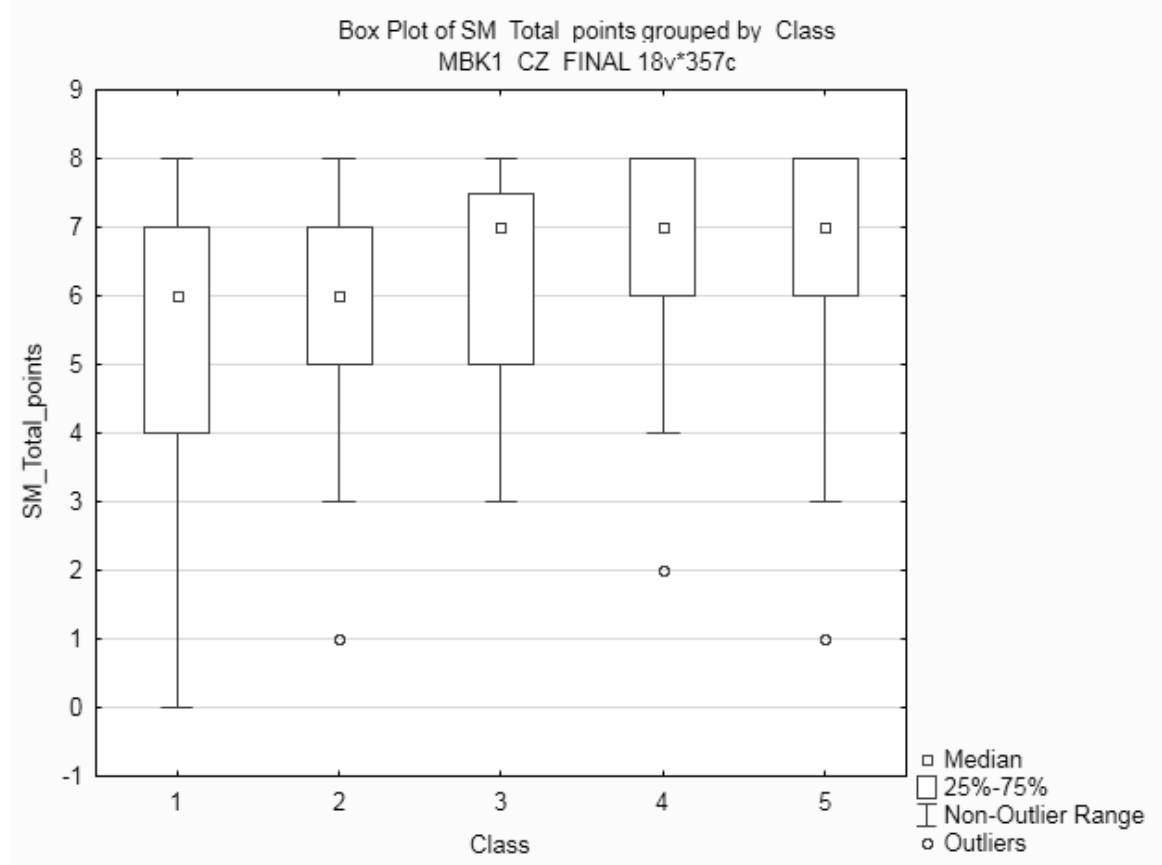

Obr. 6. Hodnoceni pohybových dovednostís vlastním tělem podle ročníků.

Ve výše uvedeném grafu se do čtvrtého ročníku zlepšuje bodové hodnocení pohybových dovedností s vlastním tělem, ale $\mathrm{v}$ pátém ročníku dochází $\mathrm{k}$ poklesu bodového hodnocení pod úroveň čtvrtého ročníku. K ideálnímu rozložení dat (z pohledu funkčnosti a využití testů) se nejvíce přibližuje první ročník. $\mathrm{V}$ prvním a druhém ročníku je medián $6 \mathrm{a}$ v třetím až pátém ročníku je medián 7 a úroveň bodového hodnocení se liší pouze velikostí bodového rozpětí v jednotlivých ročnících. 


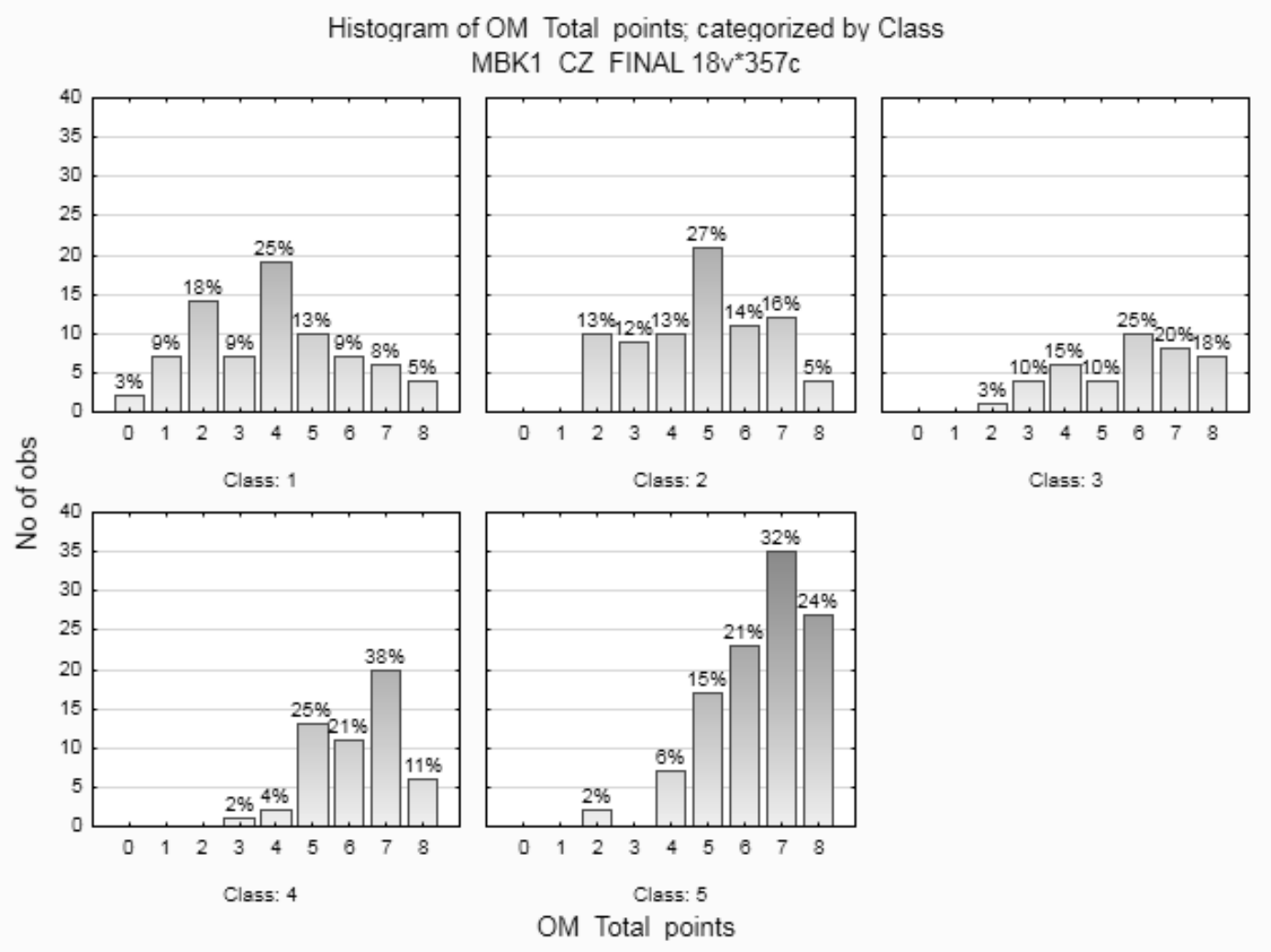

Obr. 7. Histogramy bodového hodnocení pohybových dovedností s pomůckami - ročníky.

V histogramech na obr. 7 můžeme pozorovat procentuální rozložení bodového hodnocení podle jednotlivých ročníků. Pouze v prvním ročníku jsou zastoupeny všechny bodové hodnoty. Můžeme konstatovat, že čím vyšší ročník, tím lepší procentuální zastoupení u vyšších bodových hodnot. 


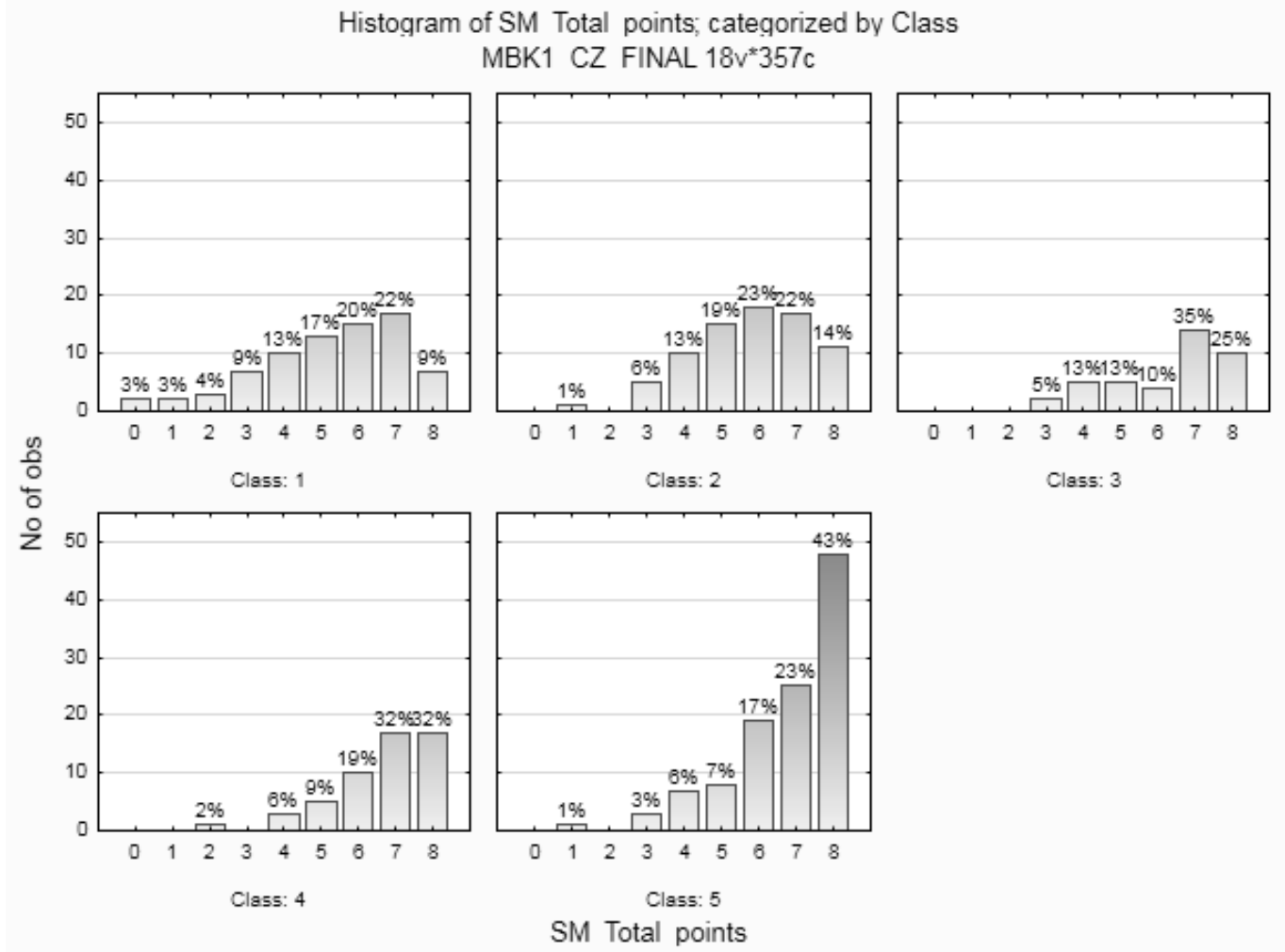

Obr. 8. Histogramy bodového hodnocení pohybových dovednostís vlastním tělem - ročníky.

V histogramech na obr. 8 můžeme pozorovat procentuální rozložení bodového hodnocení podle jednotlivých ročníků. Pouze v prvním ročníku jsou zastoupeny všechny bodové hodnoty. Můžeme konstatovat, že čím vyšší ročník, tím lepší procentuální zastoupení u vyšších bodových hodnot.

\section{Diskuse}

Na základě výsledků prvotního měření a ověřování testové baterie MOBAK 1 v České republice můžeme konstatovat, že bodové hodnocení v obou testových oblastech se zlepšuje rovnoměrně s vyššími ročníky. Pouze 5. ročník v oblasti pohybových dovedností s vlastním tělem dosahuje nepatrně horších výsledků než ročník čtvrtý.

Zjistili jsme, že hoši dosahují lepších výsledků v oblasti pohybových dovedností s pomůckou (object movement) a dívky dosahují lepších výsledků v oblasti pohybových dovedností s vlastním tělem (self movement).

K plynulému zlepšování bodového hodnocení s vyššími ročníky dochází při testování pohybových dovedností s pomůckou. S vyrovnanějším průběhem bez zjevnějšího zlepšení podle ročníků se setkáváme u testování pohybových dovedností s vlastním tělem.

Ideálnímu procentuálnímu rozložení pohybových dovedností v obou oblastech se blíží 1. a 2. třída. V ostatních ročnících (u vyšších ročníků je rozdíl výraznější) se podle histogramů procentového rozložení ukazuje, že jsou testy pohybových dovedností v obou oblastech spíš jednoduché.

Pomocí řízeného rozhovoru se zúčastněnými učiteli jednotlivých tříd jsme zjistili, že testování pohybových dovedností přijímají kladně, i když učitelé čtvrtých a pátých ročníků byli překvapeni jednoduchostí některých testů pohybových dovedností. Všichni dotázaní učitelé se také přiklonili $\mathrm{k}$ používání termínu pohybová dovednost. Zdůvodňovali to zejména použitelností v praxi. V žádném 
z testů neviděli učitelé nic problematického ve vztahu ke vzdělávacím plánům (ŠVP a RVP ZV). Zejména u testování pohybových dovedností s pomůckou si učitelé uvědomovali úzké propojení do sportovních her ve školní tělesné výchově.

Problematickou záležitostí bylo pouze vytvoření nestandardních pomůcek k měření a žonglovací míčky, které byly během měření několikrát zničeny a stálo by za úvahu jejich nahrazení např́íklad tenisovými míčky.

\section{Závěry}

Na základě zpracovaných dat lze prohlásit, že se cíl práce podařilo splnit. Získali jsme nové informace o možnostech uplatnění a realizace testové baterie MOBAK 1 ve školní tělesné výchově v České republice.

Výzkumný soubor tvořilo 357 žáků 1.-5. ročníku ZŠ. Protože nešlo o reprezentativní soubor dětí mladšího školního věku, získaná data nelze zobecnit. Přesto si dovolujeme konstatovat, že z provedeného výzkumu plynou tyto poznatky:

- Testová baterie MOBAK 1 je vhodná zejména pro 1. a 2. ročník základní školy.

- Jednotlivé testy jsou proveditelné v podmínkách školní tělesné výchovy a jsou v souladu se vzdělávacími dokumenty pro 1 . stupeň Z

- Vzhledem k prohlubování spolupráce na -mezinárodní úrovni s tvůrci testové baterie bude potřeba rozšířit výzkumný soubor MOBAK 1 a již nyní začít pracovat na ověřování testové baterie MOBAK 3 v ČR.

- Vzhledem k veliké časové náročnosti budeme rádi, pokud se najdou zájemci o spolupráci.

- Po rozšíření výzkumného souboru MOBAK 1 chceme publikovat podrobnější výsledky v odborných časopisech v České republice i zahraničí.

\section{Literatura}

DSBG4public.ch. (2016). DSBG4public.ch [Online]. Retrieved April 01, 2016, from http://www.dsbg4public.ch/

Herrmann, C., \& Seelig, H. (2014). MO B A K - 1. Motorische Basiskompetenzen in der 1. Klasse: Motorische Basiskompetenzen in der 1. Klasse [Online] (1.st ed.). Basel: Departement für Sport, Bewegung und Gesundheit (DSBG) der Universität Basel. Retrieved from Http://edoc.unibas.ch/34376/1/20140902110639_5405889f09965.pdf

Kurz, D. \& Fritz, T. (2007). Motorische Basisqualifikationen von Kindern. Ergebnisse einer repäsentativen Untersuchung in Nordrhein-Westfalen. Abschlussbericht über das Forschungsprojekt MOB AQ I und II [Basic motor qualifications of children. Results of a representative study in North Rhine-Westphalia. Final report on the research project MOB AQ I and II ]. Universität Bielefeld: Fakultät für Psychologie und Sportwissenschaft.

Kurz, D., Lindemann, U., Rethorst, S., Scheuer, C., Maatmann, H. \& Schröer, T. (2012a). Motorische Basisqualifikationen - ein pädagogisch sinnvoller Ansatz? [Basic motor qualifications - a pedagogical reasonable approach?]. Handout dvs Sektion Sportpädagogik,Jahreskonferenz 2012. Magglingen.

Měkota, K., \& Blahuš, P. (1983). Motorické testy v tělesné výchově (1. vyd.). Praha: Státní pedagogické nakladatelství.

Měkota, K., \& Cuberek, R. (2007). Pohybové dovednosti, činnosti, výkony (1. vyd.). Olomouc: Univerzita Palackého v Olomouci.

Zvolská, J., \& Gajda, V. (1986). Vybrané kapitoly z teorie tělesné kultury pro specializaci tělesné výchovy 1. stupně ZŠ. (Vyd. 1.). Ostrava: Pedagogická fakulta v Ostravě.

\section{Corresponding author}

Mgr. Marek Trávníček

Pedagogická fakulta Masarykovy univerzity, Poř́ičí 31, Brno, 60300, Česká republika

travnicek@ped.muni.cz 